\title{
Ultrasound in the postharvest treatment of grapes: impact on the extractability and phenolic composition of juice and wine
}

\section{Ultrassom no tratamento pós-colheita de uvas: impacto sobre a extratibilidade e composição fenólica do suco e vinho}

\author{
Carine Glaucia Comarella ${ }^{1 *}$; Claudia Kaehler Sautter ${ }^{2}$; \\ Mariana Ferneda Dossin ${ }^{3}$; Neidi Garcia Penna ${ }^{2}$
}

\begin{abstract}
Ultrasound has gained attention from the food industry because its properties, including chemical and physical reactions, enable a wide range of commercial applications. One of the most popular applications is the optimization of extraction of bioactive substances. Among the most recent applications is its use in postharvest of fruits and vegetables, wherein ultrasound functions as a possible elicitor agent promoting the synthesis of phenolic compounds. These substances are important in defining the chemical and sensory characteristics of juices, wines and other grape products because the concentration and extraction capacity of these compounds in grapes directly influence the product quality. Thus, this study aimed to evaluate the application of ultrasound in American and vinifera grapes of different harvests with regard to its effects on fruit extractability and concentration of phenolic compounds in elaborated juice and wine. The results indicated that, under certain conditions, ultrasound could lead to a significant increase in the anthocyanin concentration in 'Isabella' grapes and its juice. On the other hand, in 'Cabernet Sauvignon' grapes, most of the treatments did not indicate positive results in the tested parameters and tended to promote degradation of anthocyanins at significant levels. However, the observed effects varied depending on the harvest conditions and cultivar characteristics.
\end{abstract}

Key words: Acoustic cavitation. Anthocyanins. Extraction. Sonication.

\section{Resumo}

O ultrassom tem despertado interesse na indústria de alimentos uma vez que suas propriedades, as quais envolvem reações químicas e físicas, possibilitam uma larga escala de aplicações comerciais. Uma das mais exploradas é a otimização da extração de substâncias bioativas, e entre as mais recentes esta sua utilização na pós-colheita de frutas e vegetais, onde o ultrassom vem sendo testado como possível agente elicitor capaz de promover a síntese de compostos fenólicos. Estas substâncias são importantes na definição das características químicas e sensoriais de sucos, vinhos e outros produtos da uva, de forma que a concentração e a capacidade de extração destes compostos na uva influenciam diretamente a qualidade de seus produtos. Dessa forma, este estudo teve o objetivo de avaliar a aplicação do ultrassom em uvas americanas e viníferas de diferentes safras em relação aos efeitos sobre a extratibilidade no fruto e concentração de compostos fenólicos no suco e vinho elaborados. Os resultados revelam que em determinadas condições, o ultrassom pode levar a um aumento significativo da concentração de

\footnotetext{
${ }^{1}$ Farmacêutica, Dr ${ }^{\mathrm{a}}$ em Ciência e Tecnologia dos Alimentos, Departamento de Tecnologia e Ciência dos Alimentos, Universidade Federal de Santa Maria, UFSM, Santa Maria, RS, Brasil. E-mail: carineglaucia@yahoo.com.br

2 Profs. Drs., Departamento de Tecnologia e Ciência dos Alimentos, UFSM, Santa Maria, RS, Brasil. E-mail: cksautter@gmail. com; ngpenna@gmail.com

${ }^{3}$ Discente de Doutorado em Ciências Agrárias, Departamento de Solos, UFSM, Santa Maria, RS, Brasil. E-mail: marianadossin@ yahoo.com.br

* Author for correspondence
} 
antocianinas em uvas 'Isabel' e em seu respectivo suco. Já em uvas 'Cabernet Sauvignon', a maioria dos tratamentos não apresentou resultados positivos nos parâmetros testados, tendendo a promover a degradação de antocianinas em níveis significativos. No entanto, os efeitos observados variam em função das condições de safra e das características inerentes a cada cultivar.

Palavras-chave: Antocianinas. Cavitação acústica. Extração. Sonicação.

\section{Introduction}

Ultrasound (US) is a form of energy generated by sound waves at higher frequencies than those the human ear can perceive $(>20 \mathrm{kHz})$. Through frequency adjustment, US can be used in various industrial applications, including the food industry, and offers several advantages in terms of productivity, yield, and selectivity (CHEMAT et al., 2011).

The effect of US on liquid systems is mainly associated with the cavitation phenomenon which involves formation, growth, and collapse of bubbles that generate localized mechanical and chemical energy (KNORR et al., 2004). When these bubbles collapse on the surface of a solid material, they generate microjets that move towards the surface. This phenomenon mainly elicits the extraction of bioactive substances from plants due to rupture or embrittlement of the cellular membranes (ASHOKKUMAR, 2015; CHEMAT et al., 2011; CHO et al., 2006).

US is known to function as an abiotic elicitor in plant matrices and indicated a significant ability to stimulate the synthesis of secondary metabolites. Studies have shown that sonication of plant cells induce characteristic plant defense response against pathogenic infections (LIN et al., 2001). Previous studies have shown that postharvest application of US increased the content of phenolic substances in peanuts (RUDOLF; RESURRECCION, 2005; SALES; RESURRECCION, 2009) and romaine lettuce (YU et al., 2016). Few studies on grapes have demonstrated the effect of US in increasing resveratrol production in the fruit (HASAN; BAEK, 2013), as well as the enrichment of the juice and other phenolic substances (HASAN et al., 2014; COMARELLA et al., 2012).
In grape products such as juice and wine, phenolic compounds play an important role in the overall quality and definition of sensory characteristics such as color, astringency, and bitterness, as well as influencing other aspects related to the flavor and aroma (HERAS-ROGER et al., 2016). However, the concentration of these compounds in such products is not always directly related to the phenol content in grapes, since it depends, on the conditions of the fruit phenolic maturation, comprising the concentration, structure, and capacity of the compounds to be extracted (BAUTISTA-ÓRTIN et al., 2005). Phenolic maturation is strongly influenced by edaphoclimatic factors (GIL et al., 2012; HERNÁNDEZ-HIERRO et al., 2014). Moreover, the physiological conditions of the grape may significantly vary over different harvests, and interfere with processing efficiency and product quality. To the best of our knowledge, no study has considered these parameters for the evaluation of the effects of US application in grapes.

Thus, this study aimed to evaluate the application of US in American and vinifera grapes from different harvests with regard to the effects on fruit extractability and concentration of phenolic compounds in grape products such as juice and wine. Distinct periods of US post-application storage were also evaluated to investigate the time required for the effects to be observed on the fruit.

\section{Materials and Methods}

American cultivar 'Isabella' grape samples from the municipality of Itaara/RS $\left(29^{\circ} 36^{\prime} 35^{\prime \prime} \mathrm{S}\right.$, $\left.53^{\circ} 45^{\prime} 53^{\prime \prime} \mathrm{W}\right)$ collected during the 2013, 2014, and 2015 harvests were used. Vinifera grapes of 'Cabernet Sauvignon' cultivar were from Santana do Livramento/RS (3053'27"S, 55 $\left.31^{\circ} 58^{\prime \prime} \mathrm{W}\right)$ collected during the 2014 and 2015 harvests. 
In 'Isabella' grape, the measures of the industrial maturation parameters of grapes during harvest indicated the following values for total soluble solids ( ${ }^{\circ}$ Brix), $\mathrm{pH}$ and total acidity ( $\mathrm{mEq}$ of tartaric acid per liter), respectively: 16.5, 3.46, 95.0 (harvest of 2013); 17.0, 3.53, 85.0 (2014) and 16.1, 3.50, 100.0 (2015), whereas 'Cabernet Sauvignon' grape values were: 19.9, 3.56, 95.0 (2014) and 20.8, 3.60, 90.0 (2015). Grape samples were collected in the morning and stored until the following morning under controlled conditions of temperature $\left(20^{\circ} \mathrm{C}\right)$ and humidity $(\mathrm{RH} \pm 95 \%)$ to remove the field heat and allow fruit metabolism stabilization. Thereafter, the grapes were treated with US.

Sonication of samples was performed in an ultrasonic bath (Unique-USC 5000, tank dimensions: $504 \times 300 \times 150 \mathrm{~mm}, 21$ L capacity, Indaiatuba SP, Brazil) with $270 \mathrm{~W}$ rated power and frequency of $40 \mathrm{kHz}$. The experiment was run in triplicate, and the sample units consisted $1.8 \mathrm{~kg}$ of berries carefully de-stemmed to prevent the disruption of skin. US exposure times were $0,3,5$, 7 , and $10 \mathrm{~min}$. The temperature of US bath recorded after the last treatment $(10 \mathrm{~min})$ was $28.6{ }^{\circ} \mathrm{C} \pm 0.9$ on average. Then, all samples (including treatment and control) were stored for 1,3 , and 5 days at $20^{\circ} \mathrm{C}$ $(\mathrm{RH} \pm 95 \%)$ to verify the time required to observe the physiological effects of US on the grapes. After sonication, $1.8-\mathrm{kg}$ - sample content was divided into equal parts as a sample for each storage period (1, 3, and 5 days). Thereafter, the samples were immersed in liquid nitrogen and the ones selected for processing were kept at $-38{ }^{\circ} \mathrm{C}$, whereas the samples for fruit analysis were kept at $-80^{\circ} \mathrm{C}$.

The determination of grape extractability was evaluated using the phenolic potential (phenolic ripeness) analysis described by Ribéreau-Gayon et al. (2006) and Saint-Cricq et al. (1998). This technique uses an acid medium to facilitate the anthocyanin and tannin extraction from the skin and seed. The extracts obtained from the maceration of whole grapes in triturated solutions of $\mathrm{pH} 1.0$ and 3.2 to allow the determination of the total concentrations of anthocyanin and extractable anthocyanin, respectively. The difference between the results obtained in both solutions reflects the fragility of grape skin membranes and reveals the cell maturation index which is also called anthocyanin extractability index (EA\%). Grapes were crushed and macerated for $4 \mathrm{~h}$ in solutions of $\mathrm{pH} 1.0$ or 3.2 to determine this index. From the filtered and centrifuged macerate, the potential and extractable anthocyanins $\mathrm{ApH} 1.0$ and $\mathrm{ApH}$ 3.2 , respectively) were determined by the bisulfite bleaching method and the results were expressed in $\mathrm{mg} \mathrm{L}^{-1}$ of malvidin-3-glucoside (RIBÉREAUGAYON; STONESTREET, 1965). From these measurements, the cell maturation index (EA\%) was obtained using the following equation:

$$
\mathrm{EA}(\%)=\frac{A p H 1,0-A p H 3,2}{A p H 1,0} \times 100
$$

Juice was prepared from the 'Isabella' cultivar using the method described and modified by Comarella et al. (2012). The grapes were washed and crushed, then placed in $500 \mathrm{ml}$ amber glass bottles to be heated in a water bath (for $15 \mathrm{~min}$, at 85 ${ }^{\circ} \mathrm{C}$ ) for juice extraction. After natural cooling to 50 ${ }^{\circ} \mathrm{C}$, the enzyme Lafase ${ }^{\circledR}$ Fruit was added following the dosage recommended by the manufacturer. After $4 \mathrm{~h}$ of enzyme incubation, 260-parts per million (ppm) potassium metabisulfite was added. Reassembly was performed for 3 days, twice a day under controlled temperature (at $25^{\circ} \mathrm{C}$ ). Thereafter, the wort was pressed and the resulting juice was put in flasks to be heated to $50{ }^{\circ} \mathrm{C}$ for partial desulphurization. Then, the juice was cooled at 5 ${ }^{\circ} \mathrm{C}$ for 1 week for stabilization and precipitation of potassium bitartrate crystals. At the end of this period, juice aliquots were transferred to another amber glass bottle, and kept at $-38{ }^{\circ} \mathrm{C}$ until further analysis.

The wine of 'Cabernet Sauvignon' grapes was obtained by the microvinification process suggested by Miele and Rizzon (2006) after some adjustments. After crushing, each originated must was transferred 
to a 2-L fermenter and added with potassium metabisulphite. Subsequently, the enzyme Lafase ${ }^{\circledR}$ He Grand Cru (5 g $100 \mathrm{~kg}^{-1}$, Laffort ${ }^{\circledR}$ ) was added and then the yeast starter Zymaflore FX10® $(20 \mathrm{~g}$ $\mathrm{h} \mathrm{L}^{-1}$, Laffort $(\mathbb{R})$ was inoculated with the additive Superstart ${ }^{\circledR}\left(30 \mathrm{~g} \mathrm{~h} \mathrm{~L} \mathrm{~L}^{-1}\right.$, Laffort $\left.{ }^{\circledR}\right)$. After 24-h inoculation, Bioactiv ${ }^{\circledR}\left(40 \mathrm{~g} \mathrm{~h} \mathrm{~L}^{-1}\right.$, Laffort $\left.{ }^{\circledR}\right)$ was added. The wines were bottled after 3 months of stabilization, when were also collected samples for performing physical and chemical analysis.

In these products, total polyphenols (TP) were evaluated according to the method described by Singleton and Rossi (1965) and the results were expressed in equivalent gram of gallic acid per liter (GAE $\mathrm{g} \mathrm{L}^{-1}$ ). The total anthocyanin (ANTC) was determined according to Ribéreau-Gayon and Stonestreet (1965) by bleaching with sodium bisulfite, and the results were expressed in $\mathrm{g} \mathrm{L}^{-1}$ of malvidin-3-glucoside. The procyanidin content (PROC) followed the hydrolysis method in an acid medium at $100{ }^{\circ} \mathrm{C}$ described by Ribéreau-Gayon et al. (2006), and the results were expressed in $\mathrm{g}$ $\mathrm{L}^{-1}$ of cyanidin chloride. The color intensity (A420 $+\mathrm{A} 520+\mathrm{A} 620)$ and hue (A420 / A520) were determined using a spectrophotometry measuring absorbance at wavelengths $420 \mathrm{~nm}, 520 \mathrm{~nm}$ and $620 \mathrm{~nm}$ in undiluted samples of $1 \mathrm{~mm}$ optical path quartz cuvette as described by Glories (1984).

For the statistical analysis, the SAS-Statistical Analysis System v. 9.0 was used. The results were examined by the analysis of variance (ANOVA) and the differences between the treatment means were detected by the Tukey's test $(p<0.05)$.

\section{Results and Discussions}

Phenolic potential of grapes exposed to US

Table 1 presents the determination results of 'Isabella' grapes phenolic potential, treated and untreated with US (control) in the harvest of 2013 to 2015. In the evaluation of the potential anthocyanins (ApH 1.0), it was observed that US application influenced the levels of these substances depending on the exposure time of grapes. In the harvest of 2013, a 10-min sonication promoted an increase of $43 \%$ in the potential anthocyanin content in 1-day-stored samples, which continued to increase until the $5^{\text {th }}$ day. Lower doses were not effective to induce the same positive response, and could even result in anthocyanin degradation. In 2014 samples, there was a significant increase in the concentration of potential anthocyanin in almost all sonicated samples. The increase in anthocyanin content compared to the control sample (0-min-US) reached $70 \%$ after the 10 -min sonication, and posttreatment storage period of 1 day. In the following year, the sonication of grape samples resulted in a decrease in anthocyanin concentration in all tested treatments.

This disparity observed in the results of the three harvests may be due to a distinct initial state of phenolic ripeness between these grapes; as evidenced by the anthocyanin values $(\mathrm{ApH} 1.0$ and $\mathrm{ApH}$ 3.2) and cell maturity of control samples under US application. 
Table 1. Phenolic potential of 'Isabella' grapes exposed to different times of ultrasound (US) and post-treatment storage periods in 2013, 2014, and 2015 vintages.

\begin{tabular}{|c|c|c|c|c|c|c|c|c|c|}
\hline \multirow{3}{*}{$\begin{array}{c}\text { Time of } \\
\text { US }\end{array}$} & \multicolumn{2}{|c|}{2013} & \multicolumn{4}{|c|}{2014} & \multicolumn{3}{|c|}{2015} \\
\hline & $1 d * *$ & 3d & 5d & 1d & 3d & 5d & 1d & 3d & 5d \\
\hline & \multicolumn{9}{|c|}{ Potential anthocyanins (ApH 1.0) } \\
\hline $0 \mathrm{~min}$ & $351,2 \mathrm{cB} *$ & $266.6 \mathrm{aC}$ & $570.4 \mathrm{cA}$ & $347.6 \mathrm{eC}$ & $365.8 \mathrm{eB}$ & $404.8 \mathrm{dA}$ & $476.6 \mathrm{aA}$ & $301.6 \mathrm{eC}$ & $420,0 \mathrm{aB}$ \\
\hline $3 \mathrm{~min}$ & $386.2 \mathrm{bB}$ & $262.4 \mathrm{aC}$ & $438.0 \mathrm{eA}$ & $388.4 \mathrm{~dB}$ & $429.4 \mathrm{bA}$ & $385.6 \mathrm{eB}$ & $364.6 \mathrm{cC}$ & $473.0 \mathrm{aA}$ & $374.0 \mathrm{~dB}$ \\
\hline $5 \mathrm{~min}$ & $313.2 \mathrm{~dB}$ & $233.4 \mathrm{bC}$ & $578.6 \mathrm{bA}$ & $498.8 \mathrm{bA}$ & $452.0 \mathrm{aB}$ & 497.6bA & $456.8 \mathrm{bA}$ & $317.6 \mathrm{~dB}$ & $320.2 \mathrm{eB}$ \\
\hline $7 \mathrm{~min}$ & $292.2 \mathrm{eB}$ & $206.4 \mathrm{dC}$ & $560.0 \mathrm{dA}$ & $436.4 \mathrm{cB}$ & $388.4 \mathrm{dC}$ & $479.4 \mathrm{cA}$ & $229.2 \mathrm{eC}$ & $396.0 \mathrm{bA}$ & $383.8 \mathrm{cB}$ \\
\hline \multirow[t]{2}{*}{$10 \mathrm{~min}$} & $504.6 \mathrm{aB}$ & $214.6 \mathrm{cC}$ & $619.4 \mathrm{aA}$ & $591.4 \mathrm{aB}$ & $407.2 \mathrm{cC}$ & $566.4 \mathrm{aA}$ & $353.2 \mathrm{~dB}$ & $343.0 \mathrm{cC}$ & $395.2 \mathrm{bA}$ \\
\hline & \multicolumn{9}{|c|}{ Extractable anthocyanins (ApH 3.2) } \\
\hline $0 \mathrm{~min}$ & $197.8 \mathrm{bA}$ & $192.4 \mathrm{aA}$ & $190.2 \mathrm{bA}$ & $140.6 \mathrm{cA}$ & 140.0abA & $133.0 \mathrm{aA}$ & $135.4 \mathrm{bC}$ & $156.4 \mathrm{aB}$ & $215.2 \mathrm{aA}$ \\
\hline $3 \mathrm{~min}$ & $156.4 \mathrm{cC}$ & $176.2 \mathrm{bB}$ & $211.6 \mathrm{aA}$ & $152.2 \mathrm{bA}$ & $150.4 \mathrm{aA}$ & $102.6 b B$ & $154.6 \mathrm{aB}$ & $105.0 \mathrm{bC}$ & $175.0 \mathrm{bcA}$ \\
\hline $5 \mathrm{~min}$ & $246.2 \mathrm{aA}$ & $169.2 \mathrm{cC}$ & $184.4 \mathrm{cB}$ & $146.4 \mathrm{bcA}$ & $138.8 \mathrm{abA}$ & $143.0 \mathrm{aA}$ & 121.2bcB & $110.2 \mathrm{bB}$ & $216.4 \mathrm{aA}$ \\
\hline $7 \mathrm{~min}$ & $155.8 \mathrm{cB}$ & $162.8 \mathrm{dAB}$ & $185.0 \mathrm{cA}$ & $123.6 \mathrm{dA}$ & $132.2 \mathrm{bcA}$ & $129.4 \mathrm{aA}$ & $134.8 \mathrm{bB}$ & 119.6bB & $161.6 \mathrm{cA}$ \\
\hline \multirow[t]{2}{*}{$10 \mathrm{~min}$} & $224.6 \mathrm{aA}$ & $164.4 \mathrm{cdB}$ & $213.4 \mathrm{aA}$ & $187.2 \mathrm{aA}$ & $121.4 \mathrm{cB}$ & $112 \mathrm{bB}$ & $117.0 \mathrm{cB}$ & $82.8 \mathrm{cC}$ & $185.4 \mathrm{bA}$ \\
\hline & \multicolumn{9}{|c|}{ Cell maturation index (EA\%) } \\
\hline $0 \min$ & $43.7 \mathrm{bB}$ & $27.8 \mathrm{bC}$ & $66.7 \mathrm{bA}$ & $59.5 \mathrm{cB}$ & $61.7 \mathrm{~dB}$ & $67.1 \mathrm{cA}$ & $71.6 \mathrm{aA}$ & $48.2 \mathrm{~dB}$ & $48.8 \mathrm{cB}$ \\
\hline $3 \mathrm{~min}$ & $59.5 \mathrm{aA}$ & $32.9 \mathrm{aC}$ & $51.7 \mathrm{~dB}$ & $60.8 \mathrm{cC}$ & $64.9 \mathrm{cdB}$ & $72.1 \mathrm{bA}$ & $57.6 \mathrm{cB}$ & $77.8 \mathrm{aA}$ & $53.2 \mathrm{bC}$ \\
\hline $5 \mathrm{~min}$ & $21.4 \mathrm{cC}$ & $27.5 \mathrm{bB}$ & $68.1 \mathrm{aA}$ & $70.6 \mathrm{aA}$ & 69.3abA & $71.3 \mathrm{bA}$ & $73.5 \mathrm{aA}$ & $65.3 \mathrm{cB}$ & $33.7 \mathrm{dC}$ \\
\hline $7 \mathrm{~min}$ & $46.7 \mathrm{bB}$ & $21.2 \mathrm{cC}$ & $67.0 \mathrm{bA}$ & $71.6 \mathrm{aA}$ & $66.0 \mathrm{bcB}$ & $73.0 \mathrm{bA}$ & $41.2 \mathrm{dC}$ & $69.8 \mathrm{bA}$ & $57.9 \mathrm{aB}$ \\
\hline $10 \mathrm{~min}$ & $55.5 \mathrm{aB}$ & $23.4 \mathrm{cC}$ & $65.5 \mathrm{cA}$ & $68.3 \mathrm{bB}$ & $70.2 \mathrm{aB}$ & $80.2 \mathrm{aA}$ & $66.6 \mathrm{bB}$ & $75.8 \mathrm{aA}$ & $53.1 \mathrm{bC}$ \\
\hline
\end{tabular}

* Means followed by the same lower case letter in the same column and capital letter on the same line do not differ by the Tukey's test at the $5 \%$ level of significance. ** Days of storage after treatment. Values of ApH1.0 and ApH3.2 expressed in mg $\mathrm{L}^{-1}$ of malvidin-3-glucoside.

The content of extractable anthocyanin (ApH 3.2) in most of 'Isabella' grape samples was equal to (or lesser) than the control samples in 2014 and 2015 (Table 1). Significant increases $(p<0.05)$ in the concentration of these substances were more evident in the 2013 harvest in which US applications of 5 and $10 \mathrm{~min}$ verified in 1-daystored samples, and 3 and 10 min US in samples with 5 days of post-treatment storage. Most of these samples also indicated a lower cellular maturity index (EA\%) which may explain the higher content of extractable anthocyanin, because a smaller value of this index, (i.e., a smaller difference between the content of anthocyanin at $\mathrm{pH} 1.0$ and $\mathrm{pH} 3.2$ ) results in a higher extractability of these substances. This fact indicates an increase in the membrane fragility which is probably related to the effects of US in liquid systems such as the acoustic cavitation phenomenon.
US is propagated through a series of compression and rarefaction waves which travel through a medium (MASON et al., 2005). At a sufficiently high power, the rarefaction cycle may exceed the fluid molecules attraction forces and form cavitation bubbles from existing gas nuclei in the fluid. These bubbles, distributed throughout the liquid, grow during the period of a few cycles until they reach a critical size at which they become unstable and then collapse violently. When these bubbles collapse on the surface of a plant, for example, the high pressure and released temperature produce microjets that are directed to the vegetable surface and induce erosion of plant structure facilitating the release of their contents into the environment, thus increasing their extractability (CHEMAT et al., 2017).

Water molecules are broken by cavitation, generating free radicals and reactive species $\left(\mathrm{OH}^{\circ}\right.$, $\mathrm{H}_{2} \mathrm{O}_{2}$ ) as a result of the high temperature and 
pressure generated by the collapse of gas bubbles (GOGATE; KABADI, 2009). Anthocyanins and other phenolic compounds have high antioxidant activity; therefore, it is possible that they combat against the reactive species produced due to the sonication.

Oxidation reactions involving hydrogen peroxide, which causes discoloration in anthocyanins (MALACRIDA; MOTTA, 2006), can lead to the deterioration of these flavonoids, and make it difficult to establish an effective dose for US. These reactions may explain the losses observed in the anthocyanin levels in some of the treated samples. A similar result was found in a study by Hasan et al. (2014), in which the lowest concentration of phenolic compounds and anthocyanins in sonicated grapes juice has also been attributed to the $\mathrm{H}_{2} \mathrm{O}_{2}$ degradation caused by US application.

The adopted extraction method is not exhaustive, and the anthocyanin content is influenced by the method for extracting pigments as a function of fruit ripeness. However, by observing the results of extractable anthocyanins and cell maturation indices in the same harvest grapes, it was noticed that the pigment extraction was not always favored in samples exposed to US, and indicated that the observed differences between the anthocyanin content in the control and treament samples are the result of the sonication. The observed result in the sample of sonicated 'Isabella' grapes whose extractability did not increase by US application and exhibited higher potential anthocyanin content compared to the control samples (similar to most of the treatments in 2014), may suggest that US, in certain doses, has an elicitor role by acting as anabiotic stress source on the grapes.

In a study by Yu et al. (2016), US-treated-lettuce exhibited an increase in the phenylalanine ammonialyase (PAL) activity after 60-h storage, and resulted in the production of phenolic compounds and an increase in antioxidant capacity. These same biological effects may be involved, according to the authors, in the increased content of phenolic compounds (SALES; RESURRECCION, 2010) and trans-resveratrol (RUDOLF; RESURRECCION, 2005; SALES; RESURRECCION, 2009) in peanuts received sonication. Comarella et al. (2012) in their study on the effects of US application in grapes suggested that an $83 \%$ increase in phenolic compounds in the juice were due to the elicitor effect of US. Hasan and Baek (2013) also demonstrated that application of US in grapes led to trans-resveratrol accumulation in the fruit peel. This result was positively correlated with the increase in the expression of resveratrol synthase gene, suggesting that upregulation of the gene and the consequent increase in the enzyme activity by US treatment was responsible for the increase in trans-resveratrol content. According to previous studies, the intensity of the response produced by the plant depends on the concentration of the applied elicitor (VASCONSUELO; BOLAND, 2007); similarly, the dose used may be related to the time required for triggering this response.

Table 2 shows the phenolic potential of 'Cabernet Sauvignon' grapes were exposed to US treatment in 2014 and 2015. The content of potential anthocyanin (ApH 1.0), in both harvests was lower in sonicated grapes compared to the control sample in 1 day storage. In 2015, sonicated samples which were stored for 3 days had higher anthocyanin content compared to the control with the same storage period (3 days).

US use on 'Cabernet Sauvignon' grapes also did not affect the extraction of anthocyanins, because there were few positive and significant changes in the concentration of extractable anthocyanins $(\mathrm{ApH} 3.2)$ and the cell maturation index during the two seasons. However, the significant increase in the content of these substances in some samples under US treatment resulted from the weakening of the tissues which increased the extractability as indicated by a lower EA\% in these grapes. 
Table 2. Phenolic potential of 'Cabernet Sauvignon' grapes exposed to different times of ultrasound (US) and posttreatment storage periods in 2014 and 2015 vintages.

\begin{tabular}{|c|c|c|c|c|c|c|}
\hline \multirow{3}{*}{$\begin{array}{c}\text { Time of } \\
\text { US }\end{array}$} & \multicolumn{3}{|c|}{2014} & \multicolumn{3}{|c|}{2015} \\
\hline & $1 d^{* * *}$ & 3d & $5 d$ & $1 d$ & 3d & 5d \\
\hline & \multicolumn{6}{|c|}{ Potential anthocyanins (ApH1.0) } \\
\hline $0 \min$ & $833.6 \mathrm{aA} *$ & $689.0 \mathrm{aC}$ & $725.6 \mathrm{bB}$ & $616.0 \mathrm{aA}$ & $432.2 \mathrm{eC}$ & $487.6 \mathrm{bB}$ \\
\hline $3 \mathrm{~min}$ & $740.8 \mathrm{bB}$ & $659.8 \mathrm{bC}$ & $786.4 \mathrm{aA}$ & $579.2 \mathrm{bcA}$ & $522.6 b B$ & $467.2 \mathrm{cC}$ \\
\hline $5 \mathrm{~min}$ & $657.6 \mathrm{cB}$ & $644.6 \mathrm{cC}$ & $700.0 \mathrm{bA}$ & $567.6 \mathrm{cA}$ & $500.0 \mathrm{cB}$ & 498.8abB \\
\hline $7 \mathrm{~min}$ & $652.8 \mathrm{cB}$ & $598.4 \mathrm{dC}$ & $692.4 \mathrm{bA}$ & $567.0 \mathrm{cA}$ & $460.8 \mathrm{~dB}$ & $417.0 \mathrm{dC}$ \\
\hline \multirow[t]{2}{*}{$10 \mathrm{~min}$} & $574.6 \mathrm{~dB}$ & $647.0 \mathrm{cA}$ & $586.0 \mathrm{cB}$ & $580.4 \mathrm{bA}$ & $539.6 \mathrm{aB}$ & $501.0 \mathrm{aC}$ \\
\hline & \multicolumn{6}{|c|}{ Extractable anthocyanins (ApH3.2) } \\
\hline $0 \mathrm{~min}$ & $361.0 \mathrm{aA}$ & $200.6 \mathrm{cC}$ & $285.2 \mathrm{abcB}$ & $424.0 \mathrm{bcA}$ & $304.0 \mathrm{eB}$ & $306.8 \mathrm{bB}$ \\
\hline $3 \mathrm{~min}$ & $287.2 \mathrm{cdA}$ & $176.8 \mathrm{~dB}$ & $276.4 \mathrm{cA}$ & $408.4 \mathrm{cA}$ & $324.4 \mathrm{~dB}$ & $288.8 \mathrm{cC}$ \\
\hline $5 \mathrm{~min}$ & $317.6 \mathrm{bA}$ & $245.6 \mathrm{bB}$ & $252.0 \mathrm{~dB}$ & $418.8 \mathrm{bcA}$ & $351.8 \mathrm{bB}$ & $333.6 \mathrm{aC}$ \\
\hline $7 \mathrm{~min}$ & $252.6 \mathrm{~dB}$ & $285.2 \mathrm{aA}$ & $299.2 \mathrm{abA}$ & $435.8 \mathrm{bA}$ & $360.4 \mathrm{aB}$ & $287.0 \mathrm{cC}$ \\
\hline \multirow[t]{2}{*}{$10 \mathrm{~min}$} & $288.2 \mathrm{bcA}$ & $192.4 \mathrm{cB}$ & $308.6 \mathrm{aA}$ & $456.8 \mathrm{aA}$ & $333.6 \mathrm{cB}$ & $307.4 \mathrm{bC}$ \\
\hline & \multicolumn{6}{|c|}{ Cell maturation index (EA\%) } \\
\hline $0 \min$ & $56.7 \mathrm{bcB}$ & $70.9 \mathrm{bA}$ & 60.6abB & $31.1 \mathrm{aB}$ & $29.7 \mathrm{bB}$ & $37.1 \mathrm{aA}$ \\
\hline $3 \mathrm{~min}$ & $62.4 \mathrm{aB}$ & $73.2 \mathrm{aA}$ & $64.8 \mathrm{aB}$ & $29.5 \mathrm{abB}$ & $37.9 \mathrm{aA}$ & $38.2 \mathrm{aA}$ \\
\hline $5 \mathrm{~min}$ & $51.9 \mathrm{cdC}$ & $61.9 \mathrm{cB}$ & $64.0 \mathrm{aA}$ & $26.2 \mathrm{bcC}$ & 29.6bB & $33.1 \mathrm{bA}$ \\
\hline $7 \mathrm{~min}$ & 61.3abA & $52.3 \mathrm{~dB}$ & $56.8 \mathrm{cAB}$ & $23.2 \mathrm{cdB}$ & $21.8 \mathrm{cB}$ & $31.19 \mathrm{bA}$ \\
\hline $10 \mathrm{~min}$ & $49.8 \mathrm{~dB}$ & $70.2 \mathrm{bA}$ & $47.3 \mathrm{dC}$ & $21.3 \mathrm{dC}$ & $38.2 \mathrm{aB}$ & $38.6 \mathrm{aA}$ \\
\hline
\end{tabular}

*Means followed by the same lower case letter in the same column and capital letter on the same line do not differ by the Tukey's test at the 5\% level of significance. ** Days of storage after treatment. ApH1.0 and ApH3.2 results expressed in mg L ${ }^{-1}$ of malvidin3-glucoside.

According to the phenolic potential results, the sonication effect on 'Cabernet Sauvignon' grapes was smaller compared to the 'Isabella' grapes. This result may be related to differences in the skin geometry and composition in grapes. Vinifera grapes are smaller, have thicker and denser skins than the American grapes which would require a greater energy of sonication to promote embrittlement of the membranes.

It is also known that the concentration and composition of the phenolic compounds in red grapes depend on the species, cultivars, fruit ripening time and many procedures and conditions such as the vineyard management, climate, amount of solar radiation and degree of maturation (DOWNEY et al., 2006). The 'Cabernet Sauvignon' cultivar comes from the region with the most favorable climatic conditions for the grape phenolic maturity and a system provides an increased insolation of clusters. Such facts suggest that there were better ripening conditions during harvest that facilitate better development of their phenolic potential when still in the ground and reduce their response to subsequent stimuli, and promote a greater ability against free radicals emerged from sonication. In addition, vinifera varieties such as 'Cabernet Sauvignon' predominantly have monoglycosylated anthocyanins whereas American species 'Isabella' have both monoglycosylated and diglycosylated anthocyanins (RIBÉREAU-GAYON et al., 2006). This structural characteristic enhances the stability of these pigments (CASTANEDA-OVANDO et al., 2009) and may have contributed to the most satisfactory results in 'Isabella' grapes.

Phenolic composition and color of juices and wines from grapes exposed to US

Despite being important sources of phenolic compounds, products such as juice and wine 
do not necessarily have the same polyphenol concentrations as the grape from which they are originated. The processing type and the steps involved in it, especially regarding the maceration conditions, influence the extraction and therefore, the product phenol concentration (GIL et al., 2012; KENNEDY, 2008).

The concentration of phenolic compounds and color indices of grape juices made from 'Isabella' grapes subjected to different doses of US are presented in Table 3. In 2013 vintage, there was a significant increase in the total polyphenol content (TP) of the grape juice sonicated for 3 min after 1 day storage period. For this US dose, the increase was approximately $29 \%$ compared to the control. In the 2014 vintage, all juice samples from sonicated grapes with 1 day post-treatment storage showed a significant increase in the TP concentration (from 17 to $22 \%$ increase), and most of the doses in the other periods of storage. In 2015, the most significant result occurred with $5 \mathrm{~min}$ sonication in the first day of storage.

A significant increase in the juice anthocyanin content (Table 3) due to the application of US in the grapes was observed only in the harvests of 2013 and 2014 and more significantly in samples with higher post-treatment storage period (5 days). In these samples, the increase in 2013 was approximately $15 \%$ with 10 min US application, compared to the control with the same storage period (5 days), and $25 \%$ increase compared to the control sample with 1 day of storage. In 2014, the sonication of grapes for 3 min resulted in juice with a $67 \%$ higher anthocyanin concentration compared to the control sample stored for the same period (5 days) and up to $112 \%$ higher compared to the control with less storage period (1 day).
The processing of the grape for juice obtainment mainly involves a longer maceration period with the skins (3 days) which can result in a more efficient skin pigment extraction in comparison to the extraction performed for the determination of anthocyanin in the grapes phenolic potential $(4 \mathrm{~h})$. The extraction efficiency reflects not only in a higher concentration of anthocyanins in the juices in general but may also explain the higher significant difference in the content of these pigments in samples in which US had a positive effect.

For most of the sonicated 'Isabella' grape juices, there were no significant changes in the procyanidin content in all the tested harvests. However, in 2015, juice samples from grapes treated and stored for 5 days exhibited a higher procyanidin concentration compared to samples with lower storage period. This result may occur because of a better extractability as the lower values of EA\% found in the three crops (Table 1). Smaller amounts of tannins $(p<0.05)$ presented by some US treatments may be associated with other events during the juice preparation, and the interaction with other substances that are not considered and quantified by the technique used.

Regarding the determination of the color indices (intensity and hue) of the 'Isabella' grape juices (Table 3), the sonicated samples (3, 5 and $10 \mathrm{~min}$ ) from the 2014 and 2015 vintages with 1 day of storage indicated a significantly greater color intensity. The color development in the juice and wine is influenced by many factors involving complex reactions. Therefore, it is not the direct product of their anthocyanin content, as demonstrated by the results obtained from 'Isabella' grape juice. 
Table 3. Phenolic compounds and color indices in juices from 'Isabella' grapes exposed to different times of ultrasound (US) and post-treatment storage periods in 2013, 2014, and 2015 vintages.

\begin{tabular}{|c|c|c|c|c|c|c|c|c|c|}
\hline \multirow{2}{*}{$\begin{array}{c}\text { Time of } \\
\text { US }\end{array}$} & \multicolumn{3}{|c|}{2013} & \multicolumn{3}{|c|}{2014} & \multicolumn{3}{|c|}{2015} \\
\hline & $1 d^{* *}$ & 3d & $5 d$ & 1d & 3d & 5d & 1d & $3 d$ & 5d \\
\hline \multicolumn{10}{|c|}{ Total polyphenol (TP) } \\
\hline $0 \min$ & $1.49 \mathrm{cA} *$ & $1.64 \mathrm{aA}$ & 1.70abA & $1.82 \mathrm{bB}$ & $1.80 \mathrm{bB}$ & $2.53 \mathrm{aA}$ & $1.78 \mathrm{cB}$ & $1.79 \mathrm{bB}$ & $2.30 \mathrm{aA}$ \\
\hline $3 \mathrm{~min}$ & $1.92 \mathrm{aA}$ & $1.70 \mathrm{aAB}$ & $1.50 \mathrm{bB}$ & $2.19 \mathrm{aA}$ & $2.05 \mathrm{abA}$ & $2.05 \mathrm{bA}$ & $1.74 \mathrm{cB}$ & $1.56 \mathrm{bB}$ & $1.99 \mathrm{bA}$ \\
\hline $5 \mathrm{~min}$ & $1.59 \mathrm{bcA}$ & $1.51 \mathrm{aA}$ & $1.57 \mathrm{bA}$ & $2.14 \mathrm{aAB}$ & $1.86 \mathrm{abB}$ & $2.36 \mathrm{abA}$ & $2.44 \mathrm{aA}$ & $2.21 \mathrm{aA}$ & $1.87 \mathrm{bB}$ \\
\hline $7 \mathrm{~min}$ & $1.66 \mathrm{bA}$ & $1.65 \mathrm{aA}$ & $1.77 \mathrm{abA}$ & $2.22 \mathrm{aA}$ & $1.76 \mathrm{bB}$ & $2.26 \mathrm{abA}$ & $2.06 \mathrm{bA}$ & $1.66 \mathrm{bB}$ & $1.85 \mathrm{bAB}$ \\
\hline $10 \mathrm{~min}$ & $1.33 \mathrm{~dB}$ & $1.64 \mathrm{aB}$ & $1.87 \mathrm{aA}$ & $2.15 \mathrm{aB}$ & $2.15 \mathrm{aB}$ & $2.49 \mathrm{aA}$ & $2.03 \mathrm{bAB}$ & $2.25 \mathrm{aA}$ & $1.91 \mathrm{bB}$ \\
\hline \multicolumn{10}{|c|}{ Total anthocyanins (ANTC) } \\
\hline $0 \mathrm{~min}$ & $0.72 \mathrm{aA}$ & $0.74 b c A$ & $0.78 \mathrm{cA}$ & $0.56 \mathrm{cA}$ & $0.59 \mathrm{bA}$ & $0.71 \mathrm{dA}$ & $0.58 \mathrm{aA}$ & $0.54 \mathrm{abA}$ & $0.53 \mathrm{abA}$ \\
\hline $3 \mathrm{~min}$ & $0.66 \mathrm{abB}$ & $0.68 \mathrm{cB}$ & $0.87 \mathrm{abA}$ & $0.74 \mathrm{abB}$ & $0.54 \mathrm{bC}$ & $1.19 \mathrm{aA}$ & $0.60 \mathrm{aA}$ & $0.56 \mathrm{aA}$ & $0.55 \mathrm{aA}$ \\
\hline $5 \mathrm{~min}$ & $0.73 \mathrm{aB}$ & $0.79 \mathrm{abB}$ & $0.87 \mathrm{abA}$ & $0.84 \mathrm{aB}$ & $0.67 \mathrm{abB}$ & $1.08 \mathrm{bA}$ & $0.58 \mathrm{aA}$ & $0.54 \mathrm{abA}$ & $0.54 \mathrm{aA}$ \\
\hline $7 \mathrm{~min}$ & $0.70 \mathrm{aB}$ & $0.82 \mathrm{aA}$ & $0.82 \mathrm{bcA}$ & $0.71 \mathrm{bB}$ & $0.69 \mathrm{abB}$ & $0.96 \mathrm{bcA}$ & $0.62 \mathrm{aA}$ & $0.45 \mathrm{cB}$ & $0.45 \mathrm{bcB}$ \\
\hline $10 \mathrm{~min}$ & $0.61 \mathrm{bB}$ & $0.85 \mathrm{aA}$ & $0.90 \mathrm{aA}$ & $0.63 \mathrm{bcB}$ & $0.81 \mathrm{aA}$ & $0.86 \mathrm{dA}$ & $0.64 \mathrm{aA}$ & $0.48 \mathrm{bcB}$ & $0.44 \mathrm{cB}$ \\
\hline \multicolumn{10}{|c|}{ Procyanidins (PRO) } \\
\hline $0 \mathrm{~min}$ & $6.43 \mathrm{aA}$ & $5.01 \mathrm{bcB}$ & $6.01 \mathrm{aA}$ & $4.72 \mathrm{bB}$ & $5.48 \mathrm{abAB}$ & 5.86abA & $3.37 \mathrm{abC}$ & $4.21 \mathrm{aB}$ & $4.89 \mathrm{bA}$ \\
\hline $3 \mathrm{~min}$ & $5.50 \mathrm{bcA}$ & $5.38 \mathrm{abA}$ & $4.96 \mathrm{bA}$ & $4.70 \mathrm{bA}$ & $4.70 \mathrm{bA}$ & $5.13 \mathrm{bA}$ & $3.56 \mathrm{aB}$ & $3.62 \mathrm{bB}$ & $5.04 \mathrm{bA}$ \\
\hline $5 \mathrm{~min}$ & $5.39 \mathrm{bcA}$ & $5.30 \mathrm{bcA}$ & $5.50 \mathrm{abA}$ & $5.40 \mathrm{abA}$ & $5.00 \mathrm{abA}$ & 5.68abA & $2.99 \mathrm{bC}$ & $3.57 \mathrm{bB}$ & $5.58 \mathrm{aA}$ \\
\hline $7 \mathrm{~min}$ & $5.81 \mathrm{bA}$ & $5.73 \mathrm{aA}$ & $5.75 \mathrm{aA}$ & $5.48 \mathrm{abA}$ & 5.06abA & $5.87 \mathrm{abA}$ & $3.62 \mathrm{aB}$ & $3.85 \mathrm{abB}$ & $5.14 \mathrm{bA}$ \\
\hline $10 \mathrm{~min}$ & $5.21 \mathrm{cA}$ & $4.97 \mathrm{cA}$ & $5.89 \mathrm{aA}$ & $5.69 \mathrm{aA}$ & $5.74 \mathrm{aA}$ & $6.50 \mathrm{aA}$ & $3.64 \mathrm{aB}$ & 3.91abB & $5.21 \mathrm{abA}$ \\
\hline \multicolumn{10}{|c|}{ Color intensity (CI) } \\
\hline $0 \min$ & $10.57 \mathrm{abB}$ & 13.14abA & $12.55 \mathrm{bA}$ & $5.00 \mathrm{cB}$ & $6.53 \mathrm{aA}$ & $6.85 \mathrm{aA}$ & $1.98 \mathrm{~dB}$ & $4.00 \mathrm{aA}$ & $4.12 \mathrm{aA}$ \\
\hline $3 \mathrm{~min}$ & $11.57 \mathrm{aB}$ & $10.33 \mathrm{cB}$ & $14.92 \mathrm{aA}$ & $7.12 \mathrm{aA}$ & $6.45 \mathrm{aA}$ & $7.36 \mathrm{aA}$ & $3.02 \mathrm{abB}$ & $3.34 \mathrm{bAB}$ & $3.50 \mathrm{bA}$ \\
\hline $5 \mathrm{~min}$ & $11.02 \mathrm{aB}$ & $13.81 \mathrm{aA}$ & $9.26 \mathrm{cB}$ & $6.28 \mathrm{abA}$ & $6.69 \mathrm{aA}$ & $7.03 \mathrm{aA}$ & $2.65 \mathrm{cA}$ & $2.93 \mathrm{cdA}$ & $2.64 \mathrm{dA}$ \\
\hline $7 \mathrm{~min}$ & $9.00 \mathrm{bB}$ & $13.70 \mathrm{aA}$ & $11.86 \mathrm{bA}$ & $6.82 \mathrm{abAB}$ & $6.58 \mathrm{aB}$ & $7.67 \mathrm{aA}$ & $3.27 \mathrm{aA}$ & $3.24 \mathrm{bcA}$ & $3.55 \mathrm{bA}$ \\
\hline $10 \mathrm{~min}$ & $11.94 \mathrm{aA}$ & $11.72 \mathrm{bcA}$ & $12.36 \mathrm{bA}$ & $6.01 \mathrm{bB}$ & $6.68 \mathrm{aB}$ & $7.98 \mathrm{aA}$ & $2.83 \mathrm{bcA}$ & $2.71 \mathrm{~dB}$ & $3.05 \mathrm{cA}$ \\
\hline \multicolumn{10}{|c|}{ Color hue (CH) } \\
\hline $0 \mathrm{~min}$ & $0.64 \mathrm{aA}$ & $0.43 \mathrm{aB}$ & $0.46 \mathrm{abB}$ & $0.68 \mathrm{aA}$ & $0.57 \mathrm{aB}$ & $0.56 \mathrm{aB}$ & $0.24 \mathrm{bC}$ & $0.37 \mathrm{bB}$ & $0.47 \mathrm{abA}$ \\
\hline $3 \mathrm{~min}$ & $0.58 \mathrm{bA}$ & $0.46 \mathrm{aB}$ & $0.42 \mathrm{bB}$ & $0.58 \mathrm{bA}$ & $0.56 \mathrm{aA}$ & $0.52 \mathrm{aA}$ & $0.15 \mathrm{cC}$ & $0.31 \mathrm{bB}$ & $0.43 \mathrm{bA}$ \\
\hline $5 \mathrm{~min}$ & $0.55 \mathrm{bcA}$ & $0.47 \mathrm{aB}$ & $0.48 \mathrm{aB}$ & $0.52 \mathrm{bA}$ & $0.58 \mathrm{aA}$ & $0.53 \mathrm{aA}$ & $0.39 \mathrm{aB}$ & $0.37 \mathrm{bB}$ & $0.47 \mathrm{abA}$ \\
\hline $7 \mathrm{~min}$ & $0.60 \mathrm{aA}$ & $0.43 \mathrm{aB}$ & $0.46 \mathrm{abB}$ & $0.53 \mathrm{bA}$ & $0.56 \mathrm{aA}$ & $0.59 \mathrm{aA}$ & $0.25 \mathrm{bB}$ & $0.48 \mathrm{aA}$ & $0.50 \mathrm{aA}$ \\
\hline $10 \mathrm{~min}$ & $0.50 \mathrm{cA}$ & $0.46 \mathrm{aA}$ & $0.47 \mathrm{abA}$ & $0.55 \mathrm{bA}$ & $0.57 \mathrm{aA}$ & $0.52 \mathrm{aA}$ & $0.23 \mathrm{bB}$ & $0.47 \mathrm{aA}$ & $0.47 \mathrm{abA}$ \\
\hline
\end{tabular}

*Means followed by the same lowercase letters in the same column and capital letters on the same line do not differ by the Tukey's test at the $5 \%$ level of significance. ${ }^{* *}$ Days of storage after treatment. Values of TP in $\mathrm{g} \mathrm{L}^{-1}$ of Gallic acid, ANTC in $\mathrm{g} \mathrm{L}^{-1}$ of malvidin-3-glucoside and PRO in $\mathrm{g} \mathrm{L}^{-1}$ of cyanidin chloride.

Results of the phenolic compounds evaluation and color indices of wines produced from 'Cabernet Sauvignon' grapes exposed to US treatment are presented in Table 4. Compared to control samples (not sonicated), there were no beneficial and significant changes in the concentration of polyphenols and anthocyanins in wines from treated grapes. US application to the 2014 harvest resulted in a decrease $(p<0.05)$ in the anthocyanin content of the wines in which all the tested doses negatively affected the concentration of these pigments similar to what was observed in the analysis of the grape. In the 2015 harvest, US application to the fruit did not cause significant changes in the wine anthocyanin concentration except for grape samples sonicated for 7 and $10 \mathrm{~min}$ and stored for 1 day where there was a higher concentration of these substances. 
Despite the reduction in the anthocyanin content, few changes were observed in the color indices (intensity and hue) of these wines. This result may be based on the fact that in young wines, the steady state of anthocyanin may vary, so the color of red wine may be more related to the degree of ionization of the anthocyanin than their wine content. Moreover, the color of anthocyanin solutions depends on other factors such as temperature, $\mathrm{pH}$, and sulfite content.

Table 4. Phenolic compounds and color indices in wines from 'Cabernet Sauvignon' grapes exposed to different times of ultrasound (US) and post-treatment storage periods in 2014 and 2015 vintages.

\begin{tabular}{|c|c|c|c|c|c|c|}
\hline \multirow{3}{*}{$\begin{array}{c}\text { Time of } \\
\text { US }\end{array}$} & \multicolumn{3}{|c|}{2014} & \multicolumn{3}{|c|}{2015} \\
\hline & $1 d^{* *}$ & 3d & $5 d$ & 1d & 3d & 5d \\
\hline & \multicolumn{6}{|c|}{ Total polyphenol (TP) } \\
\hline $0 \mathrm{~min}$ & $2.16 \mathrm{aA} *$ & $1.90 \mathrm{bB}$ & $2.12 \mathrm{aA}$ & $2.33 \mathrm{abB}$ & $2.77 \mathrm{aA}$ & $2.56 \mathrm{aAB}$ \\
\hline $3 \mathrm{~min}$ & $2.25 \mathrm{aA}$ & $2.04 \mathrm{abA}$ & $2.05 \mathrm{abA}$ & $2.10 \mathrm{cC}$ & $2.72 \mathrm{aA}$ & $2.36 \mathrm{aB}$ \\
\hline $5 \mathrm{~min}$ & $2.06 \mathrm{aA}$ & $2.08 \mathrm{aA}$ & $2.14 \mathrm{aA}$ & $2.25 \mathrm{bB}$ & $2.50 \mathrm{bA}$ & $2.48 \mathrm{aAB}$ \\
\hline $7 \mathrm{~min}$ & $2.11 \mathrm{aA}$ & $2.06 \mathrm{abA}$ & $2.18 \mathrm{aA}$ & $2.29 \mathrm{abA}$ & $2.28 \mathrm{cA}$ & $2.390 \mathrm{aA}$ \\
\hline \multirow[t]{2}{*}{$10 \mathrm{~min}$} & $2.13 \mathrm{aA}$ & $2.06 \mathrm{abAB}$ & $1.89 \mathrm{bB}$ & $2.42 \mathrm{aA}$ & $2.37 \mathrm{bcA}$ & $2.48 \mathrm{aA}$ \\
\hline & \multicolumn{6}{|c|}{ Total anthocyanins (ANTC) } \\
\hline $0 \mathrm{~min}$ & $0.43 \mathrm{aA}$ & $0.42 \mathrm{aA}$ & $0.42 \mathrm{aA}$ & $0.25 \mathrm{bB}$ & $0.31 \mathrm{abA}$ & $0.31 \mathrm{aA}$ \\
\hline $3 \mathrm{~min}$ & $0.41 \mathrm{abA}$ & $0.35 \mathrm{bB}$ & $0.34 \mathrm{bB}$ & $0.27 \mathrm{abA}$ & $0.30 \mathrm{bA}$ & $0.30 \mathrm{aA}$ \\
\hline $5 \mathrm{~min}$ & $0.37 \mathrm{bcA}$ & $0.34 \mathrm{bA}$ & $0.35 \mathrm{bA}$ & $0.27 \mathrm{abB}$ & $0.35 \mathrm{aA}$ & $0.32 \mathrm{aA}$ \\
\hline $7 \mathrm{~min}$ & $0.38 \mathrm{bcA}$ & $0.35 \mathrm{bA}$ & $0.31 \mathrm{cB}$ & $0.28 \mathrm{aA}$ & $0.31 \mathrm{bA}$ & $0.31 \mathrm{aA}$ \\
\hline \multirow[t]{2}{*}{$10 \mathrm{~min}$} & $0.34 \mathrm{cA}$ & $0.34 \mathrm{bA}$ & $0.31 \mathrm{cA}$ & $0.28 \mathrm{aA}$ & $0.31 \mathrm{abA}$ & $0.31 \mathrm{aA}$ \\
\hline & \multicolumn{6}{|c|}{ Procyanidins (PRO) } \\
\hline $0 \mathrm{~min}$ & $1.99 \mathrm{aB}$ & $2.38 \mathrm{aA}$ & $2.17 \mathrm{aAB}$ & $1.53 \mathrm{aB}$ & $1.65 \mathrm{aB}$ & $2.23 \mathrm{bA}$ \\
\hline $3 \min$ & $2.00 \mathrm{aA}$ & $2.06 \mathrm{bA}$ & $2.07 \mathrm{abA}$ & $1.29 \mathrm{bB}$ & $1.23 \mathrm{bB}$ & $2.28 \mathrm{abA}$ \\
\hline $5 \mathrm{~min}$ & $1.93 \mathrm{abA}$ & $1.70 \mathrm{cdB}$ & $2.11 \mathrm{abA}$ & $1.06 \mathrm{cB}$ & $1.30 \mathrm{bB}$ & $2.49 \mathrm{abA}$ \\
\hline $7 \mathrm{~min}$ & $1.78 \mathrm{cA}$ & $1.92 \mathrm{bcA}$ & $1.91 \mathrm{bA}$ & $1.17 \mathrm{bcB}$ & $1.22 \mathrm{bB}$ & $2.42 \mathrm{abA}$ \\
\hline \multirow[t]{2}{*}{$10 \mathrm{~min}$} & $1.84 \mathrm{bcAB}$ & $1.64 \mathrm{~dB}$ & $1.98 \mathrm{abA}$ & $1.57 \mathrm{aB}$ & $1.54 \mathrm{aB}$ & $2.58 \mathrm{aA}$ \\
\hline & \multicolumn{6}{|c|}{ Color intensity (CI) } \\
\hline $0 \mathrm{~min}$ & $10.98 \mathrm{aA}$ & $10.92 \mathrm{aA}$ & $12.05 \mathrm{aA}$ & $8.32 \mathrm{aA}$ & $8.18 \mathrm{aA}$ & $7.99 \mathrm{aA}$ \\
\hline $3 \mathrm{~min}$ & $9.77 \mathrm{abA}$ & $10.73 \mathrm{aA}$ & $11.31 \mathrm{abA}$ & $7.70 \mathrm{aA}$ & $7.53 \mathrm{abA}$ & $7.50 \mathrm{aA}$ \\
\hline $5 \mathrm{~min}$ & $9.51 \mathrm{abA}$ & $10.27 \mathrm{abA}$ & $10.09 \mathrm{bcA}$ & $7.94 \mathrm{aA}$ & 7.60abA & $7.85 \mathrm{aA}$ \\
\hline $7 \mathrm{~min}$ & $8.82 \mathrm{bA}$ & $9.65 \mathrm{abA}$ & $10.37 \mathrm{abcA}$ & $7.64 \mathrm{aA}$ & $7.44 \mathrm{bA}$ & $7.45 \mathrm{aA}$ \\
\hline \multirow[t]{2}{*}{$10 \mathrm{~min}$} & $9.61 \mathrm{abA}$ & $9.02 \mathrm{bA}$ & $9.06 \mathrm{cA}$ & $7.77 \mathrm{aA}$ & $7.54 \mathrm{bA}$ & $7.20 \mathrm{aA}$ \\
\hline & \multicolumn{6}{|c|}{ Color hue (CH) } \\
\hline $0 \mathrm{~min}$ & $0.65 \mathrm{bcA}$ & $0.65 \mathrm{aA}$ & $0.64 \mathrm{bA}$ & $0.77 \mathrm{~ns}$ & 0.71 & 0.72 \\
\hline $3 \mathrm{~min}$ & $0.64 \mathrm{cA}$ & $0.66 \mathrm{aA}$ & $0.65 \mathrm{bA}$ & 0.72 & 0.74 & 0.75 \\
\hline $5 \mathrm{~min}$ & $0.66 \mathrm{bA}$ & $0.65 \mathrm{aA}$ & $0.65 \mathrm{bA}$ & 0.74 & 0.71 & 0.73 \\
\hline $7 \mathrm{~min}$ & $0.66 \mathrm{abA}$ & $0.65 \mathrm{aA}$ & $0.64 \mathrm{bA}$ & 0.71 & 0.73 & 0.75 \\
\hline $10 \mathrm{~min}$ & $0.68 \mathrm{aA}$ & $0.65 \mathrm{aA}$ & $0.68 \mathrm{aA}$ & 0.72 & 0.72 & 0.75 \\
\hline
\end{tabular}

*Means followed by the same lowercase letters in the same column and capital letters on the same line do not differ by the Tukey's test at the $5 \%$ level of significance. ** Days of storage after treatment. Values of TP in $\mathrm{g} \mathrm{L}^{-1}$ of Gallic acid, ANTC in $\mathrm{g} \mathrm{L}^{-1}$ of malvidin-3-glucoside and PRO in $\mathrm{g} \mathrm{L}^{-1}$ of cyanidin chloride. 
Wine procyanidin content in both harvests decreased $(\mathrm{p}<0.05)$ in most of the samples from sonicated grapes with 1 and 3 days of storage whereas the samples treated and stored for 5 days indicated no changes. This reduction is likely due to a decrease in the solubility of the procyanidin fraction present in the grape skin. The extraction capacity of these substances is related to the chemical structures which are susceptible to modification because of chemical and enzymatic reactions occur during the vinification and lead to changes in the procyanidin extractability. US may have made these substances more susceptible to reactions that favor the formation of less soluble structures. After a longer storage period (5 days), a greater embrittlement of the grape cellular structures may have helped in the extraction of these substances. Therefore, significant differences in the procyanidin content between control and treatment samples were not perceived.

Some studies in which US application was directly tested on grape products, did not obtain positive results. Zhang et al. (2016) tested the effects of US on physicochemical properties of red wine and found that there was a decrease in the total phenolic compound content. In accordance with the results of the present study, other authors have also found a decrease in the anthocyanins concentration, as a consequence of juice sonication of vinifera grapes (TIWARI et al., 2010). Testing the amplitude and time of irradiation on the prepared product (juice), the authors stated that in prolonged treatments and treatments with higher levels of energy, there was a chemical decomposition of the anthocyanin. The observed degradation was attributed to the extreme physical conditions occurred inside the cavitation bubbles during the collapse and various sonochemical reactions occurred simultaneously or separately. The water sonolysis may be responsible for the degradation because the cavitation induces the formation of hydroxyl radicals and lead to chemical decomposition (CASTELLANOS et al., 2001). Therefore, it is necessary to study under which conditions the stimulus application for the production or accumulation of phenolic compounds can overcome its consumption.

\section{Conclusions}

US post-harvest application in in natura grapes can lead to an increase in the 'Isabella' cultivar extractability and the juice phenolic compound content whereas it can also promote the degradation of anthocyanins in 'Cabernet Sauvignon' wines. These effects depend on applied sonication time and the maturation state of the grape, which makes it difficult to determine the best application condition.

\section{References}

ASHOKKUMAR, M. Applications of ultrasound in food and bioprocessing. Ultrasonics Sonochemisty, Oxford, v. 25, p. 17-23, 2015.

BAUTISTA-ÓRTIN, A. B.; MARTÍNEZ-CUTILLAS, A.; ROS-GARCÍA, J. M.; LÓPEZ-ROCA, J. M.; GÓMEZ-PLAZA, E. Improving colour extraction and stability in red wines: the use of maceration enzymes and enological tannins. International Journal of Food Science and Technology, Edinburgh, v. 40, n. 8, p. 867878, 2005.

CASTANEDA-OVANDO, A.; PACHECOHERNÁNDEZ, M. D. L.; PÁEZ-HERNÁNDEZ, M. E.; RODRÍGUEZ, J. A.; GALÁN-VIDAL, C. A. Chemical studies of anthocyanins: A review. Food Chemistry, London, v. 113, n. 4, p. 859-871, 2009.

CASTELLANOS, M. M.; REYMAN, D.; SIEIRO, C.; CALLE, P. ESR-spin trapping study on the sonochemistry of liquids in the presence of oxygen. Evidence for the superoxide radical anion formation, Ultrasonics Sonochemisty, Oxford, v. 8, n. 1, p. 17-22, 2001.

CHEMAT, F.; HUMA, Z.; KHAN, M. K. Applications of ultrasound in food technology: processing, preservation and extraction. Ultrasonics Sonochemisty, Oxford, v. 18, n. 4, p. 813-835, 2011.

CHEMAT, F.; ROMBAUT, N.; SICAIRE, A. G.; MEULLEMIESTRE, A.; FABIANO, T. A. S.; ALBERT, V. M. Ultrasound assisted extraction of food and natural products. Mechanisms, techniques, combinations, protocols and applications. A review. Ultrasonics Sonochemistry, Oxford, v. 34, p. 540-560, 2017. 
CHO, Y. J.; CHUN, H. S.; LEE, S. K.; MIN, H. Y. Ultrasonication-assisted extraction of resveratrol from grapes. Journal of Food Engineering, London, v. 77, n. 3, p. 725-730, 2006.

COMARELlA, C. G.; SAUTTER, C. K.; EBERT, L. C.; PENNA, N. G. Polifenóis totais e avaliação sensorial de suco de uvas Isabel tratadas com ultrassom. Brazilian Journal of Food Technology, Campinas, v. 15, p. 69-73, 2012.

DOWNEY, M. O.; DOKOOZLIAN, N. K.; KRSTIC, M. P. Cultural practice and environmental impacts on the flavonoid composition of grapes and wine: a review of recent research. American Journal of Enology and Viticulture, Davis, v. 57, n. 3, p. 257-268, 2006.

GIL, M.; KONTOUDAKIS, N.; GONZÁLEZ, H.; ESTERUELAS, M.; FORT, F.; CANALS, J. M.; ZAMORA, F. Influence of grape maturity and maceration length on color, polyphenolic composition, and polysaccharide content of Cabernet Sauvignon and Tempranillo wines. Journal of Agricultural and Food Chemistry, Easton, v. 60, n.32, p. 7988-8001, 2012.

GLORIES, Y. La couleur des vins rouges. $2^{\mathrm{a}}$ partie: mesure, origine et interpretation. Connaissance de la Vigne et Du Vin, Bordeaux, v. 18, n. 4, p. 253-271, 1984.

GOGATE, P. R.; KABADI, A. M. A review of applications of cavitation in biochemical engineering/biotechnology. Biochemical Engineering Journal, Amsterdam, v. 44, n. 1, p. 60-72, 2009.

HASAN, Md M.; BAEK, K. H. Induction of resveratrol biosynthesis in grape skins and leaves by ultrasonication treatment. Korean Journal of Horticultural Science \& Technology, Jeollabuk-do, v. 31, n. 4, p. 496-502, 2013.

HASAN, Md M.; YUN, H. K.; KWAK, E. J.; BAEK, K. H. Preparation of resveratrol-enriched grape juice from ultrasonication treated grape fruits. Ultrasonics Sonochemistry, Oxford, v. 21, n. 2, p. 729-734, 2014.

HERAS-ROGER, J.; DÍAZ-ROMERO, C.; DARIASMARTÍN, J. A comprehensive study of red wine properties according to variety. Food Chemistry, London, v. 196, p. 1224-1231, 2016.

HERNÁNDEZ-HIERRO，J. M.; QUIJADA-MORÍN, N.; MARTÍNEZ-LAPUENTE, L.; GUADALUPE, Z.; AYESTARÁN, B.; RIVAS-GONZALO, J. C., ESCRIBANO-BAILÓN, M. T. Relationship between skin cell wall composition and anthocyanin extractability of Vitis vinifera L. cv. Tempranillo at different grape ripeness degree. Food Chemistry, London, v. 146, p. 41$47,2014$.
KENNEDY, J. A. Grape and wine phenolics: observations and recent findings. Ciência e Investigación Agrária, Santiago, v. 35, n. 2, p. 107-120, 2008.

KNORR, D.; ZENKER, M.; HEINZ, V.; LEE, D. Applications and potential of ultrasonics in food processing. Trends in Food Science \& Technology, Cambridge, v. 15, n. 5, p. 261-266, 2004.

LIN, L.; WU, J.; HO, K. P.; QI, S. Ultrasound-induced physiological effects and secondary metabolite (saponin) production in Panax ginseng cell cultures. Ultrasound in Medicine and Biology, Oxford, v. 27, n. 8, p. 1147-1152, 2001.

MALACRIDA, C. R.; MOTTA, S. Antocianinas em suco de uva: composição e estabilidade. Boletim do Centro de Pesquisa de Processamento de Alimentos, Curitiba, v. 24, n. 1, p. 59-82, 2006.

MASON, T. J.; RIERA, E.; VERCET, A.; LÓPEZ-BUES, P. Application of ultrasound. In: SUN, D. W. (Ed.). Emerging technologies for food processing. California: Elsevier Academic Press, 2005. p. 323-350.

MIELE, A.; RIZZON, L. A. Efeito de elevadas produtividades do vinhedo nas características físicoquímicas e sensoriais do vinho Merlot. Ciência Rural, Santa Maria, v. 36, n. 1, p. 271-278, 2006.

RIBÉREAU-GAYON, P. GLORIES, Y.; MAUJEAN, A.; DUBOURDIEU, D. The chemistry of wine. In: Handbook of enology. Chichester: John Wiley and Sons, 2006. p. 1-205.

RIBÉREAU-GAYON, P.; STONESTREET, E. Le dosage des tanins du vin rouge et détermination de leur structure. Chimie Analytique, Paris, v. 48, n. 4, p. 188-192, 1965.

RUDOLF, J. R.; RESURRECCION, A. V. A. Elicitation of resveratrol in peanut Kernels by application of abiotic stresses. Journal of Agriculture and Food Chemistry, Easton, v. 53, n. 26, p. 10186-10192, 2005.

SAINT-CRICQ, N.; VIVAS, N.; GLORIES, Y. Maturité phénolique: définition et contrôle. Revue Française d'Oenologie, Paris, v. 173, p. 22-25, 1998.

SALES, J. M.; RESURRECCION, A. V. A. Maximizing phenolics, antioxidants and sensory acceptance of UV and ultrasound-treated peanuts. Food Science and Technology, London, v. 43, n. 7, p. 1058-1066, 2010.

Maximizing resveratrol and piceid contents in UV and ultrasound treated peanuts, Food Chemistry, London, v. 117, n. 4, p. 674-680, 2009.

SINGLETON, V. L.; ROSSI, J. A. Colorimetry of phenolics with phosphomolybdic-phosphotungstic acid reagents. American Journal of Enology and Viticulture, Davis, v. 16, p. 144-158, 1965. 
TIWARI, B. K.; PATRAS, A.; BRUNTON, N.; CULLEN, P. J.; O’DONNELL, C. P. Effect of ultrasound processing on anthocyanins and color of red grape juice. Ultrasonics Sonochemistry, Oxford, v. 17, n. 3, p. 598-604, 2010.

VASCONSUELO, A.; BOLAND, R. Molecular aspects of the early stages of elicitation of secondary metabolites in plants. Plant Science, Limerick, v. 172, n. 5, p. 861875, 2007.
YU, J.; ENGESETH, N. J.; FENG, H. High intensity ultrasound as an abiotic elicitor - Effects on antioxidant capacity and overall quality of romaine lettuce. Food and Bioprocess Technology, New York, v. 9, n. 2, p. 262-273, 2016.

ZHANG, Q. A.; SHEN, Y.; FAN, X. H.; GARCIA MARTÍN, J. F. Preliminary study of the effect of ultrasound on physicochemical properties of red wine. CyTA - Journal of Food, Reynosa, v. 14, n. 1, p. 55-64, 2016. 
